https://doi.org/10.37208/tgn27317

\section{The molluscs and crustaceans of Glasgow Botanic Gardens, Scotland}

\author{
R.B. Weddle \\ 89 Novar Drive, Glasgow G12 9SS \\ E-mail: richard@canto.plus.com
}

This note focuses on mollusc and crustacean species that are additional to those listed as present in Glasgow Botanic Gardens by Hancock (1999).

\section{MOLLUSCA}

Since Hancock's original On the Wildside account (Hancock, 1999) there have been several visits to the Gardens, particularly to the glasshouses, by specialist conchologists, and several bioblitzes. This note summarises the recent findings and reviews one of the historical records mentioned by Hancock.

Nineteen species have been added to Hancock's list, mainly through recording visits by Adrian Sumner (AS) on 12th February 2013 and 6th June 2015, and by Tom Walker (TW) with Peter Dance on 4th May 2016. The former recorded both in the glasshouses and outdoors, the latter pair focused on the "hot-house aliens" which, as the name suggests, are non-native species typically introduced along with plants. Some of TW's specimens were examined by Ben Rowson (BR) at the National Museum of Wales. Non-native species are indicated below by asterisks.

* Subulina octona (Bruguière, 1789) has been removed from the earlier list as the specimen found by Frew in 1906, now in the Hunterian collections, Kelvin Hall, Glasgow (catalogue number GLAHM: ZB3493), is considered to be $*$ Striosubulina striatella auct. ?non (Rang, 1831), which is perhaps the most commonly found non-native in the glasshouses (BR, pers. comm.). An empty shell found in the Palm House by TW and initially thought to be $S$. octona because it was slenderer and had more tumid whorls than the $S$. striatella present, is now considered to be the latter species because, though somewhat worn, traces of radial striae are present and the apex is rather narrow (BR, pers. comm.). There is therefore currently no definite evidence that $S$. octona is present in the glasshouses.

Species listed in the earlier account (Hancock, 1999) are not listed again in this account even if recorded since, but one species dated earlier than 1999 which has since come to light is included.

\section{Gastropoda (snails and slugs) \\ Thiaridae}

*Melanoides tuberculata (O.F. Müller, 1774). Red-rimmed melania. In a tropical pond in the Lily House (TW). There were thin and truncated Melanoides specimens found in the same pond and in the pond in the Orchid House (TW), but it is safe to assume that they too are $M$. tuberculata as it is a very variable species (BR)

\section{Arionidae}

Arion owenii Davies, 1979. Tawny soil slug (AS).

Arion rufus (Linnaeus, 1758). Large red slug (AS).

Arion subfuscus (Draparnaud, 1805). Dusky slug. Main Gardens and North Kelvin area (AS; J. Dempster, 2018).

\section{Carychiinae}

Carychium minimum O.F. Müller, 1774. Shorttoothed herald snail. Kibble Palace (TW).

\section{Helicidae}

Cepaea hortensis (O.F. Müller, 1774). White-lipped snail. Arboretum (AS); Main Gardens (A. Malcolm, 2015).

Cepaea nemoralis (Linnaeus, 1758). Brown-lipped snail. North Kelvin area (R.B. Weddle, 2011); Main Gardens

(A. Malcolm, 2018)

The absence of both Cepaea species from Hancock's list is puzzling since there are records in Glasgow generally since the late 19th century (Glasgow Museums BRC).

\section{Hygromiidae}

Trochulus striolatus (C. Pfeiffer, 1828). Strawberry snail. Disused railway tunnel (E.G. Hancock, 1994).

\section{Lauriidae}

Lauria cylindracea (Da Costa, 1778). Common chrysalis snail. Kibble Palace and Orchid House (TW).

\section{Limacidae}

*Ambigolimax nyctelius (Bourguignat, 1861). Balkan threeband slug. Kibble Palace (TW); also there and in another, unspecified, glasshouse (AS).

Lehmannia marginata (O.F. Müller, 1774). Tree slug. Kibble Palace (TW).

Limacus maculatus (Kaleniczenko, 1851). Green cellar slug. Kibble Palace (TW).

\section{Lymnaeidae}

Lymnaea stagnalis (Linnaeus, 1758). Great pond snail. In the former pond beside the Kibble Palace (M. Rutherford, 2004).

* Radix rubiginosa (Michelin, 1831). In a tropical pond in the Lily House (TW). Though more elongate and pointed than usual, the identification was confirmed by DNA (BR).

\section{Physidae}

Physella acuta (Draparnaud, 1805). European physa. Orchid House (TW).

\section{Planorbidae}

* Planorbella?duryi (Wetherby, 1879). Seminole ramshorn. In a tropical pond in the Lily House (TW). The specimens match the DNA of a Planorbella species in culture from the aquarium trade, which is perhaps P. duryi (BR).

Streptaxidae

*Streptostele musaecola (Morelet, 1860). In a "moist hothouse" (AS): this is believed to be the first British record (BR); Begonia House and Palm House (TW). 


\section{Subulinidae}

*Allopeas clavulinum (Potiez \& Michaud, 1838).

Orchid House (TW).

\section{Pelecypoda (bivalves) \\ Sphaeriidae}

Pisidium indet. Pea mussel. New pond beside Kibble Palace (Anon., RSPB, 2017).

The full list of species recorded in the Gardens, can be seen at www.gnhs.org.uk/biodiversity/GBG_splist.pdf which also gives the years when each species was first and last seen. It would seem worthwhile looking for the species on that list that have "Latest" dates in the 20th century, though some may have been lost because of habitat change, or through reconstruction of the various ponds. It is also worth noting that some quite common species, such as Arianta arbustorum (Linnaeus, 1758) and Trochulus hispidus (Linnaeus, 1758), are not listed there.

\section{CRUSTACEA}

An account of Arcitalitrus dorrieni (Hunt, 1925) is presented separately in this issue of The Glasgow Naturalist (Weddle, 2021). Otherwise, little has changed by way of crustacean records since the 1999 account (Hancock, 1999). The only other addition is a freshwater shrimp (Gammarus sp.) found in the new pond beside the Kibble Palace in 2015 (Glasgow Museums BRC). The remaining species in the 1999 list are mainly isopods (woodlice) many of which seem not to have been recorded in the Gardens for years; there is no reason to doubt their continuing presence, though, as for the molluscs, it would be useful to obtain more recent records.

The full list of crustacean species recorded in the Gardens, with the years when they were first and last seen, can be found in the species list given at the end of the Molluscs section above

With regard to the molluscs, thanks are due to Adrian Sumner and Tom Walker for many of the new records; to Maggie Reilly and Geoff Hancock for looking out specimens of Subulina in the Hunterian Museum, Glasgow; and to Ben Rowson (National Museum of Wales) who identified many of TW's specimens and made helpful comments. I am grateful also to Glasgow Museums Biological Records Centre for producing the full species lists of both molluscs and crustaceans and for details of some of the individual crustacean records that are cited.

\section{REFERENCES}

Hancock, E.G. (1999). Hidden Wildlife: the resident population of invertebrates. The Glasgow Naturalist 23(4), 59-64.

Weddle, R.B. (2021). The landhopper Arcitalitrus dorrieni (Crustacea: Amphipoda) in Glasgow Botanic Gardens, Scotland. The Glasgow Naturalist 27(3), 92-93 https://doi.org/10.37208/tgn27313 